\title{
Sterol Fractionation of Refined Olive Oil for Sale in Mediterranean Region with GC-FD, Composition Analysis of Triterpenic Dialkols and Validation
}

\section{Akdeniz Bölgesinde Satışa Sunulan Rafine Zeytinyağının GC-FD ile Sterol Fraksiyonu, Triterpenik Dialkollerin Kompozisyon Analizi ve Validasyonu}

\section{Fatma Hepsağ ${ }^{\bullet}$, Pembe Çürük}

Korkut Ata University, School of Applied Sciences, Food Technology Department, Kadirli Campus, Osmaniye, Turkey.

\section{ABSTRACT}

$\mathrm{n}$ this study, compositional analysis of the sterol fraction and triterpenic alcohols of olive oil was made assess the degree of purity of the oil and the absence of admixture with other plant oils. This determination also permited characterization of the type of olive oil. In the present work, 30 samples of olive oil supplied from the markets of Adana, Osmaniye and Mersin in 2015 and 2016 were analyzed, and the validation studies were carried out in the analysis method used. The sterol fractions were separated from the unsaponifiable fraction by silica gel plate chromatography, and later they were analyzed as the trimethylsilyl ether derivatives by capillary column gas chromatography. The validation results obtained were evaluated in accordance with TGK-Olive Oil and Pirina Oil Communiqué (Communiqué No: 2010-35).

\section{Key Words}

Olive oil, validation, sterol, GC

\section{öz}

u çalışmada, zeytinyağının sterol fraksiyonu ve triterpenik dialkollerinin kompozisyon analizi, yağın saflık derecesini ve diğer bitkisel yağlarla karışımın bulunup bulunmadığı değerlendirilmiştir. Bu tespit ayrıca, söz konusu zeytinyağı türünün karakterize edilmesine de izin vermiştir. Bu çalışmada, 2015 ve 2016 yıllarında Adana, Osmaniye ve Mersin marketlerinden elde edilen 30 adet zeytinyağı örneği analiz edilmiş ve kullanılan analiz yönteminde validasyon çalışmaları yapıımıştır. Sterol fraksiyonları, silika jel plakası kromatografisi ile ayrışamayan fraksiyondan ayrıldı ve daha sonra kılcal kolon gazı kromatografisi ile trimetilsilil eter türevleri olarak analiz edildi. Elde edilen validasyon sonuçları TGK-Zeytinyağı ve Pirina Oil Communiqué (Tebliğ No: 2010-35) ile değerlendirildi.

\section{Anahtar Kelimeler}

Zeytinyağı, validasyon, sterol, GC. 


\section{INTRODUCTION}

0 lives, one of the oldest cultivated plants in the world; It belongs to the subspecies of Oleaceae family, Olea genus, Olea europa strain, Olea europa sativa [1]. Olive is a typical Mediterranean plant that grows in warm and rainy winters and warm and dry in summers [2].

The qualities of olive oil vary depending on the applications of olive, plant growth, cultivation time, geographical and ecological conditions of growing place and degreasing methods [2-4]. Natural olive oil will not be able to defeat high acid, bad taste and smell are refined to reduce acidity. Refining is a kind of cleaning process Only the unwanted aspects of the oil are eliminated. No foreign substance is added. At the end of this process however, the peculiar flavor and odor of the olive oil also disappear. This acid-free, odorless and colorless oil is then recycled to $10-15 \%$ of its biological properties lost by mixing with natural oil. These oils are sold in the market as "riviera".

Natural olive oil consists of two parts, saponifying (98$99 \%)$ and non-saponifying $(0,5-2 \%)[5,6]$. The triglycerides, mono-diglycerides, free fatty acids and fololipids present in the saponifying fraction of about $98-99 \%$ of the olive oil and the other $1-2 \%$ constitute the phenolic substances, tocopherols, sterols, squalene, carotenoids and chlorophyll in the non-saponifying fraction $[7,8]$. Sterols are natural components that appear in many plant and animal species. They are also essential for human and animal dietary requirements. The sterol fraction is considered to be important for evaluation of the purity of oil samples. The sterol fraction has also been used to typify olive oils from certain geographic zones and to control their authenticity [9].

It is aimed to determine the characteristics of the production of olive oils, techniques, preparation, processing and marketing according to the legislation. In this context, quality and purity criteria determined according to different oil types are monitored regarding meeting consumer rights and expectations and protection of human health. Sterol determination is the most important method in determining the purity of olive oil and determining the extent of the attack. Total sterol content and sterol composition should be determined to determine whether other vegetable oils are mixed with olive oil. This condition can be detected by sterol analysis even if prina oil is added. Sterol detection is carried out using the chromatographic apparatus and mainly using the Gas Chromatography-Flame Ion Detector (GC-FID) system.

This study aimed to determine the amount of 30 refined olive oil and pyrene oils (Olive oil factories in the olive oil dish after the squeezing of olives is called pirina. Pirina consists of oil, water, core and pulp. In general, 15-22 $\mathrm{kg}$ of olive oil from $100 \mathrm{~kg}$ olive oil, $35-45 \mathrm{~kg}$ of pirina is obtained. Pirina oil is used in soap, paint and similar industries. It is also possible to use this oil as cooking oil, for example, in Italy, $98 \%$ of this oil is consumed as edible. In a study conducted in our country, it was stated that certain conditions were complied with and that if the pyrexia was dried and dried, the criteria of the physical and chemical properties of this oil would be very close to the criteria given for olive oil and the prina oil would carry the edible oil) supplied by the markets of Adana, Osmaniye and Mersin in 2015 and 2016, compositional analysis of the sterol fraction and triterpenic dialcohols with capillary colon gas chromatography and in the mediterranean region.

\section{MATERIALS and METHODS}

\section{Preparation of Samples}

The olive oil samples from the original unopened package from the grocery store were kept in the refrigerator at $+3 /+4^{\circ} \mathrm{C}$ until analytical reception. In our study, 30 refined olive oil and pirina oils were used. Also validation studies have been carried out in the analysis method used.

\section{Analysis Procedures}

Firstly, $\alpha$-cholestanol was added to the olive oil samples, so that the material was saponified with ethanolic potassium hydroxide and then the non-saponified materials were extracted with diethyl ether. The fraction of sterol and triterpenic alcohols was separated from the other non-saponified materials by thin layer chromatography on a basic silica gel plate. After preparation of the sterol and triterpenic dialcohol band trimethylsilyl esters on the plate, the capillaries were injected for column GC injection. 


\section{Used chemicals}

Potassium hydroxide: At least 85\% pure, 2 M Ethanolic potassium hydroxide solution, Ethyl ether: Analytical purity, $0.2 \mathrm{M}$ ethanolic potassium hydroxide solution, Anhydrous sodium sulfate: Analytical purity, Glass plates: 20x10 TLC plate ready for use, Acetone: Chromatographic purity, n-hexane: Chromatographic purity, Ethyl ether: Chromatographic purity, Ethanol: Analytical purity, Ethyl acetate: Analytical purity, Anhydrous pyridine: Chromatographic purity, Hexamethyl disilizane: Analytical purity, Trimethylchlorosilane: Analytical purity, Sterol trimethylsilyl ether reference solutions, n-hexane/ ethyl ether 65: $1(\mathrm{w} / \mathrm{v})$ solution of phenolphthalein: 10 g / (v/v), Carrier gases: High purity hydrogen, Auxilary gases: High purity hydrogen, nitrogen and dry air.

\section{Analysis by Gase Chromatography}

Chromatograms were obtained using a Shimadzu brand GC (serial no. C11915100684) instrument. The inlet of the column is connected to the split injection system and the outlet is connected to the gas chromatograph by connecting to the detector. A general check of the gas chromatograph is made (gas flow, the activity of detector and recorder etc.). Working conditions; Heater 20-35 cm/s, hydrogen $30-50 \mathrm{~cm} / \mathrm{s}$, split ratio: 1 : 1 , temperature of furnace: $260 \pm 5^{\circ} \mathrm{C}$, injection temperature: $280-300^{\circ} \mathrm{C}$, detector temperature: $280-300^{\circ} \mathrm{C}$, linear velocity of carrier gas: 50-1: 100 range, device accuracy: between 4 and 16 times the lowest value, quantity of injected substance: 0.5-1 $\mu \mathrm{L}$ trimethylsilyl ester solution.

\section{Evaluation and Calculation of Result}

The identification of each peak was made by comparing the retention times and the retention times of the sterol and triterpene alcohol trimethylsilyl esters analyzed under the same conditions [10]. Retention times for $\beta$-sitosterol for SE-52 and SE-54 columns are given in Table 1.

Table 1. Retention times for sterols and triterpene dialcohols.

\begin{tabular}{|c|c|c|c|c|}
\hline \multirow{2}{*}{ Pig } & \multicolumn{2}{|r|}{ Definition } & \multicolumn{2}{|c|}{ Relative retention time (minutes) } \\
\hline & Trade Name & IUPAC Name & $\begin{array}{l}\text { SE } 54 \\
\text { Column }\end{array}$ & $\begin{array}{c}\text { SE } 52 \\
\text { Column }\end{array}$ \\
\hline 1 & cholesterol & $\Delta$-5-cholesten-3 $\beta$-ol & 0.67 & 0.63 \\
\hline 2 & cholestanol & $5 \alpha$-cholestan-3 $\beta$-ol & 0.68 & 0.64 \\
\hline 3 & brassicasterol & 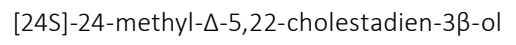 & 0.73 & 0.71 \\
\hline$*$ & ergosterol & [24S]-24-methyl- $\Delta-7-22$-cholestatrien-3 $\beta$ ol & 0.78 & 0.76 \\
\hline 4 & 24-methylene-cholesterol & 24-methylene- $\Delta-5,24$-cholestan-3 $\beta$-ol & 0.82 & 0.80 \\
\hline 5 & campesterol & (24R)-24-methyl- $\Delta-5$-cholestan-3 $\beta$-ol & 0.83 & 0.81 \\
\hline 6 & campestanol & (24R)-24-methyl-cholestan-3ß-ol & 0.85 & 0.82 \\
\hline 7 & stigmasterol & (24R)-24-ethyl- $\Delta-5,22$-cholestadien-3 $\beta$-ol & 0.88 & 0.87 \\
\hline 8 & $\Delta$-7-campesterol & (24R)-24-methyl- $\Delta$-7-cholestan-3 $\beta$-ol & 0.93 & 0.92 \\
\hline 9 & $\Delta$-5,23-stigmastadienol & (24R,S)-24-ethyl- $\Delta-5,23$-cholestadien-3 $\beta$-ol & 0.95 & 0.95 \\
\hline 10 & klerosterol & (24S)-24-ethyl- $\Delta-5,25$-cholastadien-3 $\beta$-ol & 0.96 & 0.96 \\
\hline 11 & $\beta$-sitosterol & (24R)-24-ethyl- $\Delta$-5-cholestan-3 $\beta$-ol & 1.00 & 1.00 \\
\hline 12 & sitostanol & 24-ethyl-cholestan-3ß-ol & 1.02 & 1.02 \\
\hline 13 & $\Delta$-5-avenasterol & (24Z)-24-ethyliden-5-cholestan-3ß-ol & 1.03 & 1.03 \\
\hline 14 & $\Delta$-5.24-stigmasthadienol & (24R,S)-24-ethyl- $\Delta-5,24$-cholestadien-3 $\beta$-ol & 1.08 & 1.08 \\
\hline 15 & $\Delta$-7-stigmasthenol & (24R,S)-24-ethyl- $\Delta-7,24$-cholestadien-3 $\beta$-ol & 1.12 & 1.12 \\
\hline 16 & $\Delta$-7-avenasterol & (24Z)-24-ethyliden- $\Delta$-7-cholestan-3 $\beta$-ol & 1.16 & 1.16 \\
\hline 17 & erithrodiol & $5 \alpha$ oleate-12en-3 $\beta 28$ diol & 1.41 & 1.41 \\
\hline
\end{tabular}


Table 2. Total Sterol repeatability studies in refined olive oil.

\begin{tabular}{ccc}
\hline & 1. analyst & 2. analyst \\
\hline 1 & 2361.26 & 1948.88 \\
\hline 2 & 1699.02 & 1791.65 \\
\hline 3 & 1966.36 & 1868.20 \\
\hline 4 & 2039.87 & 1789.86 \\
\hline 5 & 2334.81 & 1999.76 \\
\hline Xort $(\mathrm{mg} / \mathrm{kg})$ & 2025.00 & 2457.88 \\
\hline $\mathrm{Sr}(\mathrm{mg} / \mathrm{kg})$ & 2071.06 & 1976.04 \\
\hline $\mathrm{RSDr}(\%)$ & 247.49 & 250.51 \\
\hline$r(\mathrm{mg} / \mathrm{kg})$ & 0.12 & 0.13 \\
\hline \hline
\end{tabular}

\section{Calculation of the Amount of Sterol}

The amount of each sterol was calculated in $\mathrm{mg} / \mathrm{kg}$ as follows [10].

$$
\text { sterolx }=\frac{\mathrm{A}_{\mathrm{x}} \times m_{s} \times 1000}{\mathrm{~A}_{\mathrm{s}} \times m}
$$

Calculation of triterpen dialcohols

Calculation of erythrodiol and uvaol percentage uvaol [10].

$$
\%(\text { eritrodio } 1+\text { uvaol })=\frac{\mathrm{Er}+\mathrm{Uv}}{\mathrm{Er}+\mathrm{Uv}+\sum \mathrm{A}} \times 100
$$

\section{Evaluation of Results}

The amount of each sterol was calculated, for example, in $\mathrm{mg} / \mathrm{kg}$ and the sums were calculated in $\mathrm{mg} / \mathrm{kg}$ as total sterols. The percentage of each sterol was calculated from the ratio of the corresponding peak area to the total peak area of the sterols [10].

$\%$ sterol $x=\frac{A_{x}}{\sum A} \times 100$

\section{RESULTS and DISCUSSION}

Within the scope of the method validation studies; Detection limit and measurement limit, linear measurement range, reproducibility, reproducibility and backwardness by two analysts achievement studies were made.

\section{Repeatability}

By two analysts; 6 pieces of recovery work were done in the case of olive oil. For the repeatability limit (r); I. and II. analyst data were separately calculated according to the following formula: $r=2.8 \times \mathrm{sr}$ (standard deviation). Total sterol repeatability studies in refined olive oil were given in Table 2, and erythrodiol and uvole repeatability studies in refined olive oil were given in Table 3.

Table 3. Triterpenic dialcohols (Erythrodiol and Uvaol) repeatability studies in refined olive oil.

\begin{tabular}{ccc}
\hline & 1. analyst & 2. analyst \\
\hline 1 & 2.47 & 3.16 \\
\hline 2 & 3.28 & 3.19 \\
\hline 3 & 2.02 & 2.35 \\
\hline 4 & 2.57 & 2.29 \\
\hline 5 & 2.50 & 2.28 \\
\hline $\operatorname{Xort}(\%)$ & 2.70 & 2.40 \\
\hline $\operatorname{Sr}(\%)$ & 2.59 & 2.61 \\
\hline $\operatorname{RSDr}(\%)$ & 0.41 & 0.44 \\
\hline$r(\%)$ & 0.16 & 0.17 \\
\hline
\end{tabular}


Table 4. Total sterol reproducibility studies in refined olive oil.

\begin{tabular}{ccc}
\hline & 1. analyst & 2. analyst \\
\hline 1 & 2361.26 & 2164.34 \\
\hline 2 & 1699.02 & 2188.04 \\
\hline 3 & 1966.36 & 2044.20 \\
\hline 4 & 2039.87 & 1950.21 \\
\hline 6 & 2334.81 & 2106.56 \\
\hline 7 & 2025.00 & 1902.14 \\
\hline 8 & 2322.59 & 1948.88 \\
\hline 10 & 1670.56 & 1791.65 \\
\hline 11 & 1680.48 & 1868.20 \\
\hline 12 & 1667.04 & 1789.86 \\
\hline Xort $(\mathrm{mg} / \mathrm{kg})$ & 2347.56 & 1999.76 \\
\hline $\mathrm{Sr}(\mathrm{mg} / \mathrm{kg})$ & 1650.19 & 2457.88 \\
\hline $\mathrm{RSDr}(\%)$ & 1980.40 & 2017.64 \\
\hline $\mathrm{r}(\mathrm{mg} / \mathrm{kg})$ & 301.61 & 190.98 \\
\hline
\end{tabular}

\section{Reproducibility}

I. and II. The reproducibility data of the analyst was evaluated as reproducibility data. Reproducibility limit (R); Calculated according to the formula $\mathrm{R}=2.8 \times \mathrm{Sr}$. F test was applied to standard deviations obtained from the results of two analysts. Since the difference between the standard deviations between the individuals was in significant, the reproducibility standard deviations were obtained by combining the data of the two analysts and here reproducibility limits were found as shown in Table 4 and Table 5.

Table 4. Total sterol reproducibility studies in refined olive oil.

\begin{tabular}{|c|c|c|}
\hline & 1. analyst & 2. analyst \\
\hline 1 & 2.47 & 3.16 \\
\hline 2 & 3.28 & 3.19 \\
\hline 3 & 2.02 & 2.35 \\
\hline 4 & 2.57 & 2.29 \\
\hline 5 & 2.50 & 2.28 \\
\hline 6 & 2.70 & 2.40 \\
\hline 7 & 2.88 & 2.24 \\
\hline 8 & 2.66 & 2.28 \\
\hline 9 & 3.07 & 2.29 \\
\hline 10 & 3.02 & 2.16 \\
\hline 11 & 3.06 & 1.90 \\
\hline 12 & 2.73 & 1.66 \\
\hline Xort (\%) & 2.75 & 2.35 \\
\hline
\end{tabular}




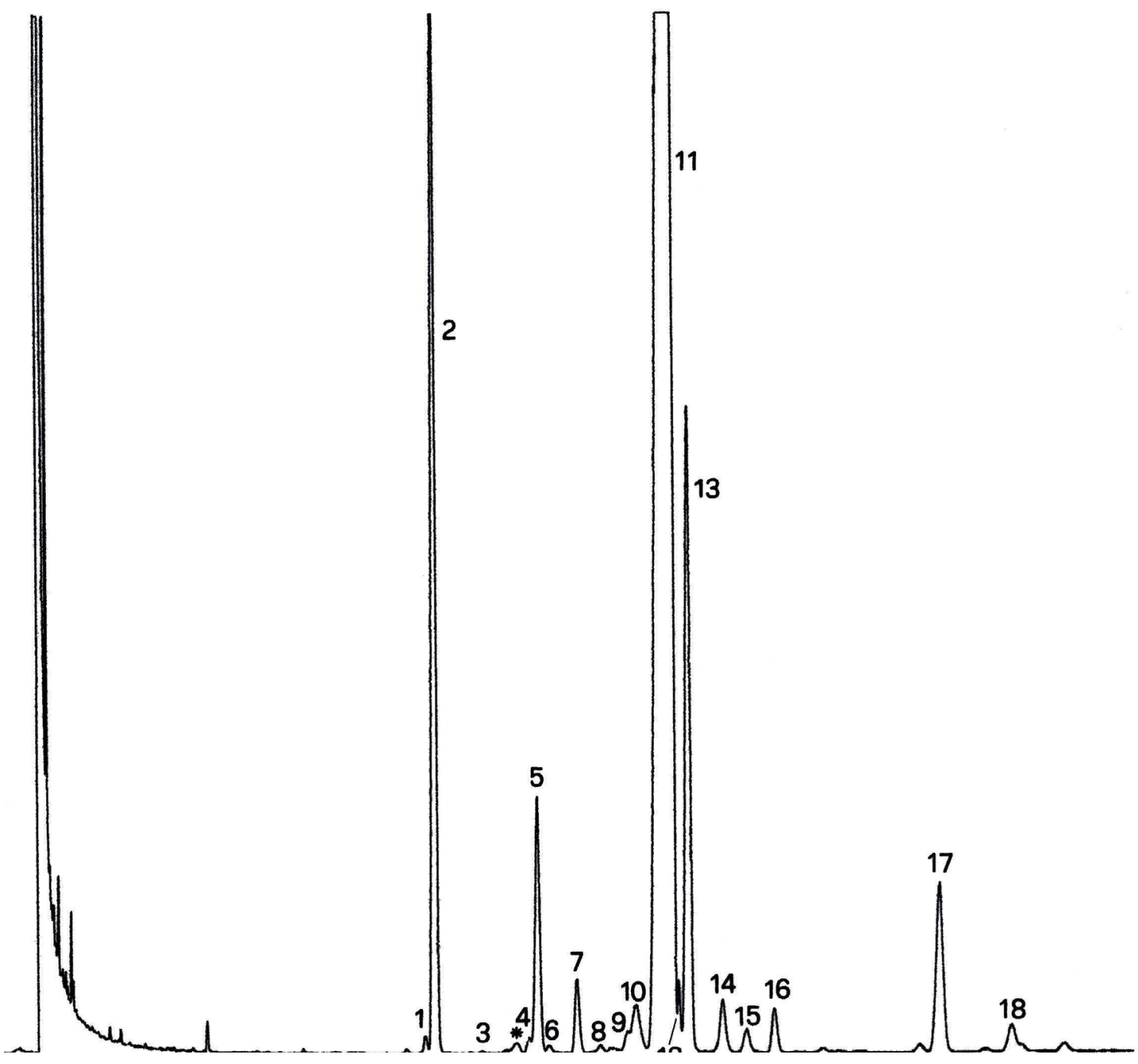

Figure 1. Gas chromatogram of the fraction of sterol and refined olive oil.

Forty three olive (Olea europaea L.) cultivars from the World Olive Germplasm Bank, IFAPA Centro 'Alameda de Obispo', Cordoba, Spain were studied for their oil sterol composition and total content. The main sterols found in olive oil were $\beta$-sitosterol, $\Delta 5$-avenasterol, campesterol and stigmasterol, most of them showing high variability. Most cultivars showed total sterol contents within the limits established by EU regulations, although $28 \%$ of virgin olive oil analysed were outside the limits established for total content and/or for individual sterols. Over the group of cultivars, total sterol contents ranged from 855 to $2185 \mathrm{mg} / \mathrm{kg}$ [11]. In another study, seven wild olive trees were identified by examining sterol and triterpenic dialkol compounds with those of virgin olive oil obtained from Chemlali and Chetoui olives cultivated plants grown under the same pedoclimatic
conditions.The main sterol found in all the samples is $\beta$ Sitosterol, followed by $\Delta 5$-avenasterol. MAT22 oleaster shows the highest value for $\beta$-sitosterol (87.18\%), whereas SB12 oleaster is characterised by the lowest percentage of $\beta$-sitosterol (71\%) and the highest one of $\Delta 5$ avenasterol (21.73\%). For the remaining varieties, the levels of b-sitosterol and $\Delta-5$-avenasterol are within the range of $74-86 \%$ and $4-17 \%$, respectively. Sterol content of oils was below the upper legal limit of $4 \%$ in all nalysed samples, with a range from $1.05 \%$ to $3.40 \%$ [12].

Free and esterified sterol concentrations in 31 edible oils and fats were determined, including individual values for sitosterol, campesterol, stigmasterol, brassicasterol, $\Delta 5$-avenasterol, sitostanol, campestanol, and cholesterol [13]. Considerable variability in the proportion 
of free and esterified sterols was observed among different oils and fats, with free sterols ranging from 32 to $94 \%$ of total sterols. Refining or hydrogenation tended to decrease total sterols and increase Esterified sterols. Differences in total phytosterol content and the proportion of free and esterified sterols also were evident for different samples of some oils. Among four soybean oils, total phytosterols ranged from 205 to $287 \mathrm{mg} / 100$ $\mathrm{g}$, and free sterols constituted $68-81 \%$ of total sterols; two different shortenings differed $62 \%$ in total sterol content (185-301mg/100 g). Such variability in phytosterol composition likely reflects differences in processing, growing season, or the variety of a particular plant source. In 2008 determined the first liquid chromatographic method for the identification and quantification of seven phytosterols in olive oil. Sterols were identified and quantified by liquid chromatography with mass spectrometry detection in positive APCI (atmospheric pressure chemical ionisation) mode. The method presented values between 123 and $677 \mathrm{ng} / \mathrm{mL}$ for detection limits, with relative standard deviations between $4.0 \%$ and $5.4 \%$ at a concentration of $5 \mathrm{mg} / \mathrm{L}$ for each sterol [14].

When we examine our other studies and research results on this issue, total sterol was found between 1699 and 2347 and Triterpenic dialcohols (Erythrodiol and Uvaol) was found between 1.66 and 2.28. It has been determined that the recovery rates, reproducibility and standard deviation values of reproducibility percentage according to the obtained results are following the acceptance criteria specified in the TGK - Olive Oil and Pyrine Oil Communiqué $[15,16]$. These results are similar to those reported by other workers in other olive-growing zones [17]. Salvador et al. [18] describe sterol profiles similar for the Cornicabra cv. A similar case has been cited by Guillaume et al. [19] for Frantoio, Barnea and Picual cvs., grown in Australia and by Giuffrè and Louadj for Cassanese, Coratina, Itrana, leccino, Nociara, Ottobratica, Peudolino, Picholine and Sinopese cvs. grown in the area of Rizziconi (South West Calabria) $[20,21]$.

\section{CONCLUSION}

The sterol and erythrodiol + uvaol composition is an indicator of the authenticity of virgin olive oil. Sterols are the main constituents of the unsaponificable fraction, with their content corresponding to approximately 20 $\%$ of the oil's total unsaponificable matter. All of the sterols in our work are within the limits established by EU regulations.

\section{References}

1. A. Kiritsakis, P. Markasis, Olive Oil: A Review. Department of Food Science and Human Nutrition, Michigon State University, East Landing, Michigon, 1997.

2. M. Çolakoğlu, Analytical Characters of Turkish Olive Oil Obtained in the Campaign of 1967-1968. E.Ü.Z.F. Publications. Publication No.194, Izmir. 1972.

3. A. Oktar, M. Çolakoğlu, Effects of agronomic factors on olive oil quality, Bursa 1st International Food Symposium, April 4-6, Bursa (1989), 477-485.

4. J. A. Pereira, S. Casal, A. Bento, M.B.P.P. Oliveira, Influence of olive storage period on oil quality of three portuguese cultivars of oleo europe, cobrancuosa, madural, and verdeal transmontana, J. Agric. Food Chem., 50 (2002) 6335-6340.

5. J.F. Cavalli, X. Fernandez, L. Lizzani-Cuvelier, A.M. Loiseau, Characterization of Volatile Compounds of French and Spanish Virgin Olive Oils by HS-SPME: Identification of Quality-Freshness Markers, Food Chem., 88 (2004) 151-157.

6. A. Ranalli, L. Lucera, S. Contento, N. Simone, P. Delre, Bioactive Constituents, Flavors and aromas of virgin oils obtained by processing olives with a naturel enzyme extract, Eur. J. Lipid Sci. Technol., 106 (2004) 187-197.

7. D. Boskou, Olive oil chemistry and technology, Department of Chemistry Aristotle University of Thessaloniki. Thessaloniki, Greece, 1996.

8. S.A. Ardo, Characterization of olive oils commercially available in The United States, Department of Nutrition and Food Science, University of Maryland, MS Thesis, (2005), 132.

9. M.G. Bagur-González, E. Pérez-Castaño, M. Sánchez-Viñas, D. Gázquez-Evangelista, The use of liquid chromatographic finger printing of the sterol fraction to separate extra virgin olive oil from other traceable oils J. Chromatogr. A, 1380 (2015) 64-70.

10. TGK Communiqué on Methods of Analysis of Olive Oil and Pyrine Oil (Communiqué No: 2014/53), 2014

11. O. Kycyk, M.P. Aguilera, J.J. Gaforio, A. Jimenez, G. Beltran, Sterol composition of virgin olive oil of forty-three olive cultivars from the World Collection Olive Germplasm Bank of Cordoba, J. Sci. Food Agric., 96 (2016) 4143-4150.

12. B. Baccouri, H. Manai, J.S. Casas, E. Osorio, M. Zarrouk, Tunisian wild olive (Olea europaea L. subsp. oleaster) oils: sterolic and triterpenic dialcohol compounds, Ind. Crop. Prod., 120 (2018) 11-15.

13. M. Katherine Phillips, M. David RuggioJari, I. Toivo Molly, A. Swank Amy, H. Simpkins, Free and esterified sterol composition of edible oils and fats, J. Food Comp. Anal., 15 (2002) 123-142.

14. B. Cañabate Díaz, A. Segura Carretero, A. Fernández Gutierrez, A. Belmonte Vega, Separation and determination of sterols in olive oil by HPLC-MS, Food Chem., 102 (2007) 593-598. 
15. Communiqué Pertaining to the amendment of TGK. Olive Oi and Pirina Oil (Communiqué No: 2010/35) (Communiqué No: 2014/54) 2014.

16. European Union Commission Regulation EEC/2568/91 Characteristics of olive and olive pomace oils and their analytical methods and subsequent amendments (latest: EU Commission Implementing Regulation 1348/2013 of the Commission of 16 December. EU Off J L 338 (2013) 31-67.

17. J. Sánchez, E. Osorio, A.M. Montaño, M. Martínez, Sterol and erythrodiol + uvaol content of virgin olive oils from cultivars of Extremadura (Spain), Food Chem. 87 (2004) 225-230.
18. M.D. Salvador, F. Aranda, G. Fregapane, Influence of fruit ripening on "Cornicabra" virgin olive oil quality. A study of four successive crop seasons Food Chem., 73 (2001) 45-53.

19. C. Guillaume, L. Ravetti, D.L. Ray, J. Johnson, Technological factors affecting sterols in australian olive oils J. Am. Oil Chem. Soc., 89 (2012) 29-39.

20. A.M. Giuffre, Steroli, Eritrodiolo e Uvaolo in olio di oliva da cultivar coltivate in Calabria, Ind. Aliment. 51 (2012) 20-26.

21. A.M. Giuffre, L. Louadj, Influence of crop season and cultivar on sterol composition of monovarietal olive oils in Reggio Calabria (Italy), Czech J. Food Sci. 31 (2013) 256-263. 